\title{
BIEGUNY WZROSTU PODKARPACIA W KONTEKŚCIE CZTERECH SIŁ KONKURENCYJNOŚCI ORAZ STRATEGII ROZWOJU WOJEWÓDZTWA
}

\author{
THE GROWTH POLES IN PODKARPACKIE VOIVODESHIP \\ IN THE CONTEXT OF THE FOUR FORCES OF COMPETITIVENESS \\ AND THE REGIONAL DEVELOPMENT STRATEGY
}

Nr DOI: $10.25167 / \mathrm{sm} 2018.029 .05 \quad$ s. $77-90$

\begin{abstract}
ABSTRAKT: W artykule autorzy analizują zapisy dokumentów strategicznych oraz wyniki prowadzonych badań ewaluacyjnych dotyczących miast w województwie podkarpackim, ze szczególnym uwzględnieniem ośrodków uznanych za bieguny wzrostu. Ich sytuacja obecna oraz perspektywy rozwojowe odniesione zostają do koncepcji czterech sił konkurencyjności (zasobów wewnętrznych, popytu zewnętrznego, dominacji, sieci). Badania, na których oparto zasadniczą treść artykułu, przedstawiają sytuację kompleksowo - zarówno w ujęciu statycznym, jak i dynamicznym, z uwzględnieniem trendów na przyszłość. Szczególne miejsce w opracowaniu zajmuje stolica regionu - Rzeszów (wraz z obszarem metropolitalnym) z tej racji, że w aktualnej Strategii rozwoju województwa jest to jedyny ośrodek, któremu poświęcono oddzielny priorytet. Także w przypadku pozostałych biegunów wzrostu autorzy starają się jednak wychwycić pewną ich specyfikę.

SŁOWA KLUCZOWE: biegun wzrostu, konkurencyjność, miasto, ośrodek subregionalny, strategia rozwoju

ABSTRACT: In the article the authors analyze the records of strategic documents and the results of conducted evaluation studies concerning cities in Podkarpackie Voivodeship, with a particular emphasis on centers considered to be the province's growth poles. Their present situation and development perspectives are referred to the concept of four competitiveness forces (internal resources, external demand, domination, networks). The studies on which the essence of the article is based, present the situation comprehensively both in static and dynamic terms, taking into account future trends. The capital city of the region - Rzeszów (with the metropolitan area) has a special place in the study, as it is the only city to be given a separate priority in the current development strategy. In the case of the other growth poles, the authors also try to capture some of their specificities.
\end{abstract}

KEY WORDS: city, competitiveness, development strategy, growth pole, sub-regional centre

\footnotetext{
* Uniwersytet Warszawski, Wydział Geografii i Studiów Regionalnych, Zakład Rozwoju i Polityki Lokalnej, e-mail: bil.m@wp.pl,w.dziemianowicz@uw.edu.pl.
} 


\section{Wprowadzenie}

Od wielu lat badacze starają się wyjaśnić główne czynniki rozwoju regionalnego i lokalnego, podejmując zagadnienia m.in. ekonomiczne, społeczne, kulturowe czy przyrodnicze. W wymiarze przestrzennym następuje koncentracja uwagi na miastach, a w szczególności na metropoliach, które traktowane są jako kluczowe ośrodki wzrostu w skali globalnej. Jednocześnie toczy się dyskusja nad kierunkami i instrumentami polityk rozwoju EU, krajów członkowskich oraz polityk regionalnych, których celem jest z jednej strony rozwój terytoriów, z drugiej zaś zapobieganie rosnącym zróżnicowaniom społeczno-ekonomicznym.

Skierowanie uwagi badaczy i polityków na silne ośrodki wzrostu, w połączeniu z dominującym obecnie paradygmatem innowacyjności, pozwala teorii biegunów wzrostu nie tylko być trwałym fundamentem modelu polaryzacyjno-dyfuzyjnego, ale również przedmiotem dociekań i „ponownych odkryć” istoty koncepcji F. Perroux (1955).

Polityki rozwoju krajów i regionów, których egzemplifikacją są strategie różnych szczebli administracji publicznej, zawierają od niedawna silnie akcentowany wymiar terytorialny realizacji celów ${ }^{1}$. Dotyczy to nie tylko strategii krajowych czy dużych organizacji międzynarodowych, jaką jest UE, ale również województw, a nawet pojedynczych gmin.

W przypadku Polski uznanie największych miast za bieguny wzrostu, wpływające na rozwój całego kraju, zaowocowało wskazaniem „lepszego wykorzystania potencjałów najważniejszych obszarów miejskich do kreowania wzrostu i zatrudnienia oraz stymulowania rozwoju pozostałych obszarów" jako pierwszego ze strategicznych wyzwań Krajowej Strategii Rozwoju Regionalnego (s. 24). W 2015 roku uchwalono również dokument w całości poświęcony tematyce rozwoju miast - Krajowa Politykę Miejska 2023. Należy jednak zwrócić uwagę, że koncentrowanie działań rozwojowych w metropoliach nie jest rozwiązaniem powszechnie uznanym za słuszne. Wiele opracowań planistycznych, a także dokumentów europejskich (m.in. Europejska Perspektywa Rozwoju Przestrzennego, Agenda Terytorialna Unii Europejskiej, Zielona Karta Spójności Terytorialnej) zwraca uwagę na policentryczność systemu osadniczego. Policentryczność ma dawać szanse na zmniejszenie różnic w poziomie rozwoju między różnymi obszarami, wzrost konkurencyjności i zapewnienie trwałego rozwoju (Smętkowski 2013).

W artykule podejmujemy próbę odpowiedzi na pytanie: w jaki sposób podmioty kreujące politykę intraregionalną planują wpływać na rozwój regionalnych biegunów wzrostu w kontekście koncepcji czterech sił konkurencyjności (zasoby wewnętrzne, popyt zewnętrzny, dominacja, sieci)? Koncepcja czterech sił konkurencyjności traktowana jest tu jako płaszczyzna analizy, zaś przedmiotem analizy są miasta, a konkretnie

\footnotetext{
${ }^{1}$ Co nie oznacza, że problemy regionalne, zagadnienie zróżnicowań regionalnych i polityka przestrzenna nie były wcześniej przedmiotami badań geografów, socjologów i planistów. Zwracamy jednak uwagę na fakt, że „sektorowe” podejście, które dominowało i wciąż stara się dominować, „zmuszane” jest coraz częściej do uwzględniania wymiaru terytorialnego również w kontekście formułowania celów strategicznych.
} 
bieguny wzrostu określone w Strategii rozwoju województwa - Podkarpackie 2020. Opierając się na konkretnych zapisach tego dokumentu, dokonujemy analizy jakościowej umożliwiającej określenie sposobu interwencji polityki zarządu województwa w poszczególne bieguny wzrostu.

\section{Bieguny wzrostu i siły konkurencyjności}

Koncepcja biegunów wzrostu F. Perroux (1955) omawiana była w literaturze wielokrotnie (Grzeszczak 1978, 1999; Gawlikowska-Hueckel 2003). W tym kontekście interesujące są badania, których celem było nie tylko wskazanie biegunów, ale również określenie ich funkcji (Szlachta 2011; Wojnicka-Sycz 2013). Bieguny wzrostu rozpatrywane są zarówno jako zjawisko pojawiające się w przestrzeni, jak i czynnik regionotwórczy (Dziemianowicz 2011). Dużo miejsca poświęca się relacjom biegun-otoczenie, które przybierają postać polaryzacji (Grzeszczak 1971; Nowicka 2011; Wojnicka-Sycz 2013).

Bieguny wzrostu i procesy polaryzacyjne na trwałe weszły do dyskusji na temat czynników rozwoju regionalnego i lokalnego (por. Nelson 1993; Higgins, Savoie 1997; Malizia, Feser 1999; Grosse 2002; Dunford 2003). Traktując bieguny wzrostu jako miejsca nagromadzenia określonych zasobów, które to miejsca mają siłę oddziaływania na otaczające je terytoria, można rozpatrywać bieguny w różnych skalach - zarówno metropolitalnej, aglomeracyjnej, jak i mniejszych ośrodków miejskich (por. Smętkowski 2013; Wojnicka-Sycz 2013). Kluczowe pozostaje pytanie, co decyduje o sile danego bieguna i zakresie jego oddziaływania na otoczenie. Różnorodne koncepcje sięgają do wielu czynników. Przykładowo M. Dunford (2003) wskazuje na czynniki podsystemu ekonomicznego (technologia i system produkcji, baza surowcowa) oraz czynniki zawarte w podsystemie kulturowo-instytucjonalnym. Z kolei A. Płoszaj (2007), dokonując przeglądu literatury, grupuje czynniki w cztery kapitały: naturalny, gospodarczy, społeczny i ludzki. Innym podejściem jest koncepcja czterech sił konkurencyjności (Dziemianowicz 2008). Zakłada ona, że konkurencyjność regionu czy gminy zależy od siły zasobów wewnętrznych, siły popytu zewnętrznego, siły dominacji oraz siły sieci. Dwie pierwsze siły odpowiadają na pytanie: Co decyduje o konkurencyjności gminy? W przypadku zasobów wewnętrznych są to wszystkie podmioty zlokalizowane na obszarze danej jednostki, ale również istotne są ich cechy. Z kolei siłę popytu zewnętrznego także budują podmioty zlokalizowane na terenie jednostki, jednak tylko te, które potrafią konkurować na rynkach zewnętrznych i umiejętnie zaspokajają popyt zewnętrzny. Siła dominacji oraz siła sieci dopowiadają na pytanie: W jaki sposób gminy uzyskują konkurencyjność? W pierwszym przypadku istotna jest przewaga danej jednostki nad innymi, dzięki czemu następuje wykorzystanie efektu skali, innowacyjności, a w konsekwencji dochodzi do absorpcji z otoczenia czynników zwiększających konkurencyjność. W przypadku sieci istotna jest przede wszystkim współpraca i wielostronne relacje, np. w ramach poczwórnej helisy (Leydesdorff 2012). Zatem o budowaniu potencjału rozwojowego nie musi decydować skala (jak w sile dominacji), a umiejętność współpracy w wartościowych sieciach. 
W tak zarysowanej koncepcji teoria biegunów wzrostu w największym stopniu odpowiada sile dominacji, jednak należy podkreślić, że opieranie rozwoju na jednej z sił może nie być wystarczające w konkurencji długofalowej. Odwołując się do dywersyfikacji zasobów, wydaje się, że najlepszą pozycję mają te miasta i gminy, które potrafią wykorzystywać każdą z wymienionych sił.

\section{Ośrodki miejskie w województwie podkarpackim - procesy rozwojowe}

Na obszarze województwa podkarpackiego znajduje się 51 miast. Najliczniejsze (34 miasta) są ośrodki niewielkie, poniżej 10 tys. mieszkańców ${ }^{2}$. Największym miastem jest stolica regionu - Rzeszów, który zamieszkuje ponad 187 tys. mieszkańców ${ }^{3}$, co daje miastu 18. miejsce w Polsce ${ }^{4}$. Stalowa Wola, Mielec i Przemyśl to ośrodki z liczbą mieszkańców przekraczającą 60 tys., Tarnobrzeg, Krosno, Dębica liczą sobie 40-50 tys. mieszkańców, zaś Sanok, Jarosław i Jasło - 30-40 tys. Mimo obecności takich miast Podkarpacie jest regionem o najniższym w kraju współczynniku urbanizacji wynoszącym jedynie $41,3 \%$.

Przyjmując, że w zasadzie każde miasto może pełnić funkcję bieguna wzrostu, oczywiście w odpowiedniej skali, warto zwrócić uwagę na sytuację miast województwa podkarpackiego, zarówno w ujęciu statycznym, jak i dynamicznym (Dziemianowicz 2016a). Stosując uproszczoną miarę rozwoju społeczno-gospodarczego jako syntezę stanu (rok 2015) i zmian (lata 2004-2015), można wyciągnąć pewne interesujące wnioski dotyczące wszystkich miast w regionie (ryc. 1).

Tylko dwa miasta - Rzeszów i Nowa Dęba - zaliczają się do grona liderów (w obu zestawieniach - statycznym i dynamicznym - plasują się wysoko - czyli w pierwszej piętnastce miast ${ }^{5}$ ). Rzeszów stanowi rdzeń najważniejszego w regionie bieguna wzrostu, który będzie się rozwijał dzięki wzmacnianiu funkcji metropolitalnych. Z punktu widzenia całego województwa istotne jest stworzenie we współpracy z Rzeszowem sprawnego systemu wymiany wiedzy i doświadczeń w obszarze wszystkich miast regionu. Istotne są również m.in. dobre połączenia komunikacyjne z innymi ośrodkami subregionalnymi. Z kolei Nowa Dęba rozwija się nieco „w cieniu” znacznie większych

2 66\% podkarpackich miast odznacza się liczbą ludności nieprzekraczającą 10 tys. osób, tymczasem w skali kraju jest to tylko $55 \%$.

3 Stan na koniec 2016 r.

4 Koncepcja Przestrzennego Zagospodarowania Kraju 2030 (KPZK) klasyfikuje Rzeszów w gronie ośrodków wojewódzkich o znaczeniu krajowym, ale poza grupą miast o podstawowym znaczeniu dla systemu osadniczego kraju.

5 Syntetyczny wskaźnik rozwoju społeczno-gospodarczego (zarówno w podejściu statycznym, jak i dynamicznym) skonstruowany został na podstawie dwóch wskaźników cząstkowych: wskaźnika rozwoju gospodarczego - mierzonego dochodami własnymi per capita budżetu gminy oraz wskaźnika rozwoju społecznego - mierzonego liczbą ludności. Do konstrukcji wskaźników zastosowano metodę taksonomicznej miary rozwoju Z. Hellwiga. Punktem odniesienia dla miast województwa podkarpackiego były miasta zidentyfikowane w ramach przeprowadzonej analizy benchmarkingowej, co pozwoliło na przeprowadzenie analizy porównawczej stanu rozwoju społeczno-gospodarczego (Łukomska 2016). 


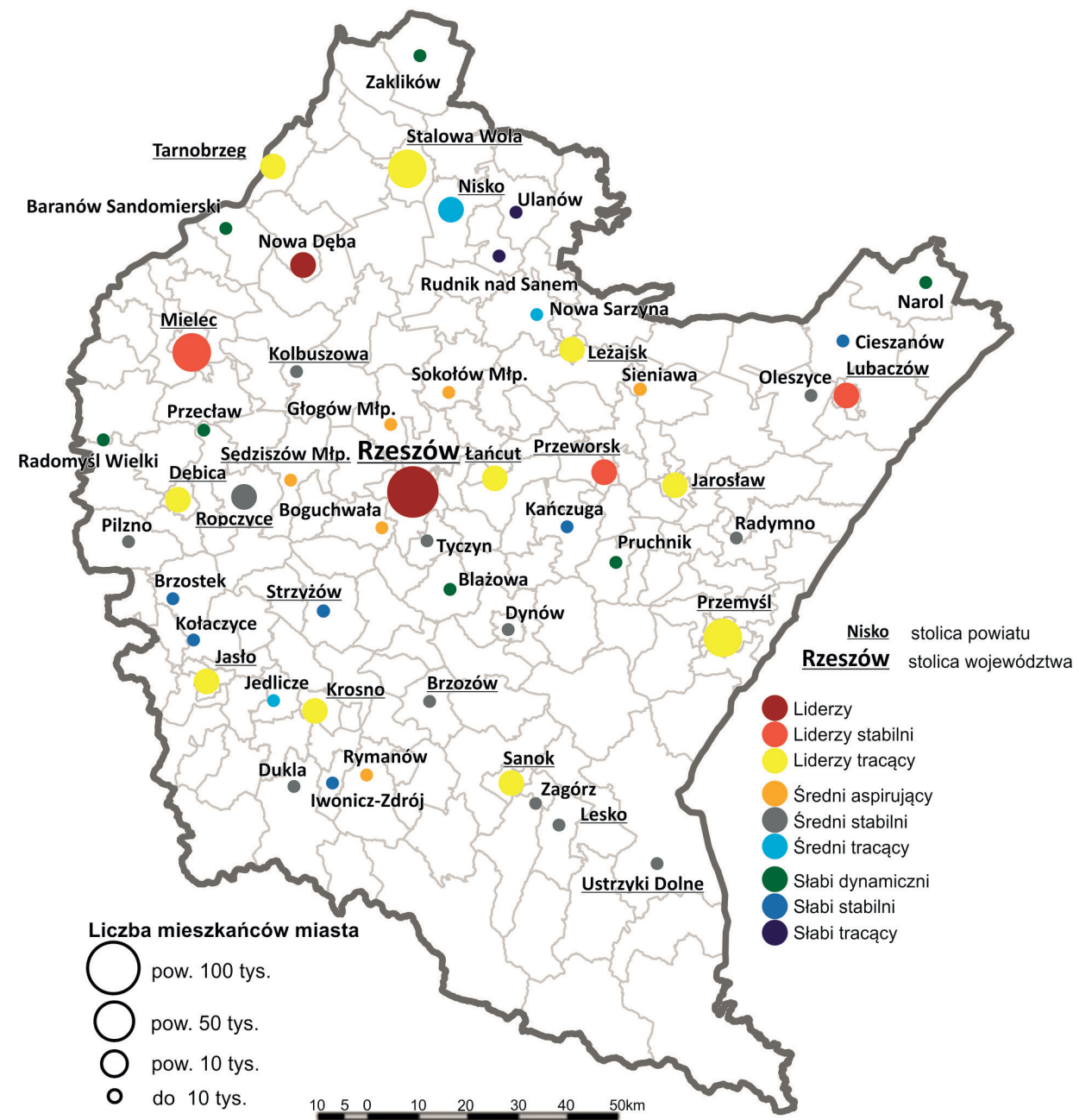

Ryc. 1. Poziom i dynamika rozwoju społeczno-gospodarczego - grupy miast

Źródło: Dziemianowicz 2016a, s. 177.

ośrodków w oparciu o potencjał turystyczny i gospodarczy. Kluczowe jest pytanie, czy Nowa Dęba będzie skutecznie aspirowała do roli trzeciego wierzchołka w trójkącie z Tarnobrzegiem i Stalową Wolą.

Mielec oraz Przeworsk (a także Lubaczów) znalazły się w grupie „liderów stabilnych” (miasta zaliczane do najlepszej piętnastki w rankingu za 2015 r., ale plasujące się na miejscach od 16. do 36. w zestawieniu dynamiki zmian). Wzmocnienie szans rozwojowych tych ośrodków powinno polegać na aktywizacji podmiotów gospodarczych na rzecz inteligentnych specjalizacji, rozwoju inicjatyw klastrowych (poza Mielcem, gdzie są już one wystarczająco rozwinięte), w przypadku Lubaczowa również rozwoju 
współpracy międzynarodowej - głównie w oparciu o przejście graniczne w Budomierzu i wykorzystanie potencjału współpracy z miastami bliźniaczymi (z Ukrainy i Słowacji). Istotne powinno być również wsparcie funkcji społecznych - rozwój kapitału ludzkiego w zakresie szkolnictwa zawodowego (Mielec), wzrost dostępności do usług publicznych (medycznych - w Przeworsku) oraz poprawa dostępności komunikacyjnej (zwłaszcza w przypadku Mielca).

W gronie „liderów tracących” (miast zaliczonych do pierwszej piętnastki w poziomie rozwoju społeczno-gospodarczego w 2015 r., ale znajdujących się w ostatniej piętnastce miast ze względu na zmiany w latach 2004-2015) znajduje się większość miast, które w dalszej części artykułu będą rozpatrywane jako bieguny wzrostu z punktu widzenia działań strategicznych. Są to m.in.: Stalowa Wola, Tarnobrzeg, Przemyśl, Krosno, Dębica, Jarosław, Sanok, Łańcut. Dynamikę rozwoju miast zaliczonych do tej grupy mają poprawić przede wszystkim: lepsze wykorzystanie potencjału związanego $\mathrm{z}$ występującymi w miastach inteligentnymi specjalizacjami (i wpisanie tego w sieci współpracy), tworzenie jak najlepszej infrastruktury technicznej w wyznaczonych strefach aktywności gospodarczej, rozwój inicjatyw klastrowych, lepsze wykorzystanie sąsiedztwa z Ukrainą i Słowacją w przypadku miast położonych blisko granicy, wzmacnianie kapitału ludzkiego, budowa więzi społecznych, rozwój infrastruktury oraz oferty spędzania wolnego czasu, usprawnienie i rozwój połączeń komunikacyjnych (zwłaszcza realizowanie wspólnych projektów miast rdzeniowych i gmin je otaczających). Również w tym przypadku wypełnienie zaleceń ma poskutkować poprawą konkurencyjności miast we wszystkich czterech obszarach. Jedno z miast rdzeniowych, Ropczyce, zostało zaliczone do grupy „średnich stabilnych” (środkowa grupa miast zarówno we wskaźniku statycznym, jak i dynamicznym). Postulowane działania w zakresie rozwoju funkcji gospodarczych powinny obejmować pobudzanie lokalnej przedsiębiorczości, zwłaszcza wsparcie inicjatyw sieciowych i lepsze wykorzystanie atutu położenia (siła zasobów wewnętrznych, siła sieci). Ponadto dla tego miasta postulowane jest wsparcie kształcenia ustawicznego.

W gronie zazwyczaj niewielkich miast słabych (ostatnia piętnastka w rankingu rozwoju społeczno-gospodarczego) sześć ośrodków należy do grupy stabilnych (w okresie 2004-2015), siedem charakteryzowała w tym czasie wysoka dynamika wzrostu, zaś w przypadku dwóch ośrodków nastąpiło relatywnie znaczące osłabienie pozycji (Rudnik nad Sanem oraz Ulanów). Warto podkreślić, że miasta słabe, jeśli wykazują znaczącą poprawę sytuacji, charakteryzują się umiejętnością wykorzystania korzystnego położenia (np. względem innych miast), relatywnie wysoką atrakcyjnością osiedleńczą (z terenów okolicznych gmin) lub wykorzystaniem walorów turystycznych.

\section{Wzmocnienie biegunów wzrostu w świetle zapisów strategii wojewódzkiej}

W Strategii rozwoju województwa - Podkarpackie 2020 wskazano dziewięć biegunów wzrostu traktowanych jako obszary strategicznej interwencji w zakresie konkret- 
nych działań ${ }^{6}$ (ryc. 2). Zidentyfikowanymi rzeczywistymi biegunami wzrostu na terenie województwa podkarpackiego są: Rzeszów, Krosno, Mielec, Przemyśl, Tarnobrzeg, Stalowa Wola oraz duopole: Dębica-Ropczyce, Jarosław-Przeworsk i Sanok-Lesko (Komornicki, Śleszyński, Siłka 2012).

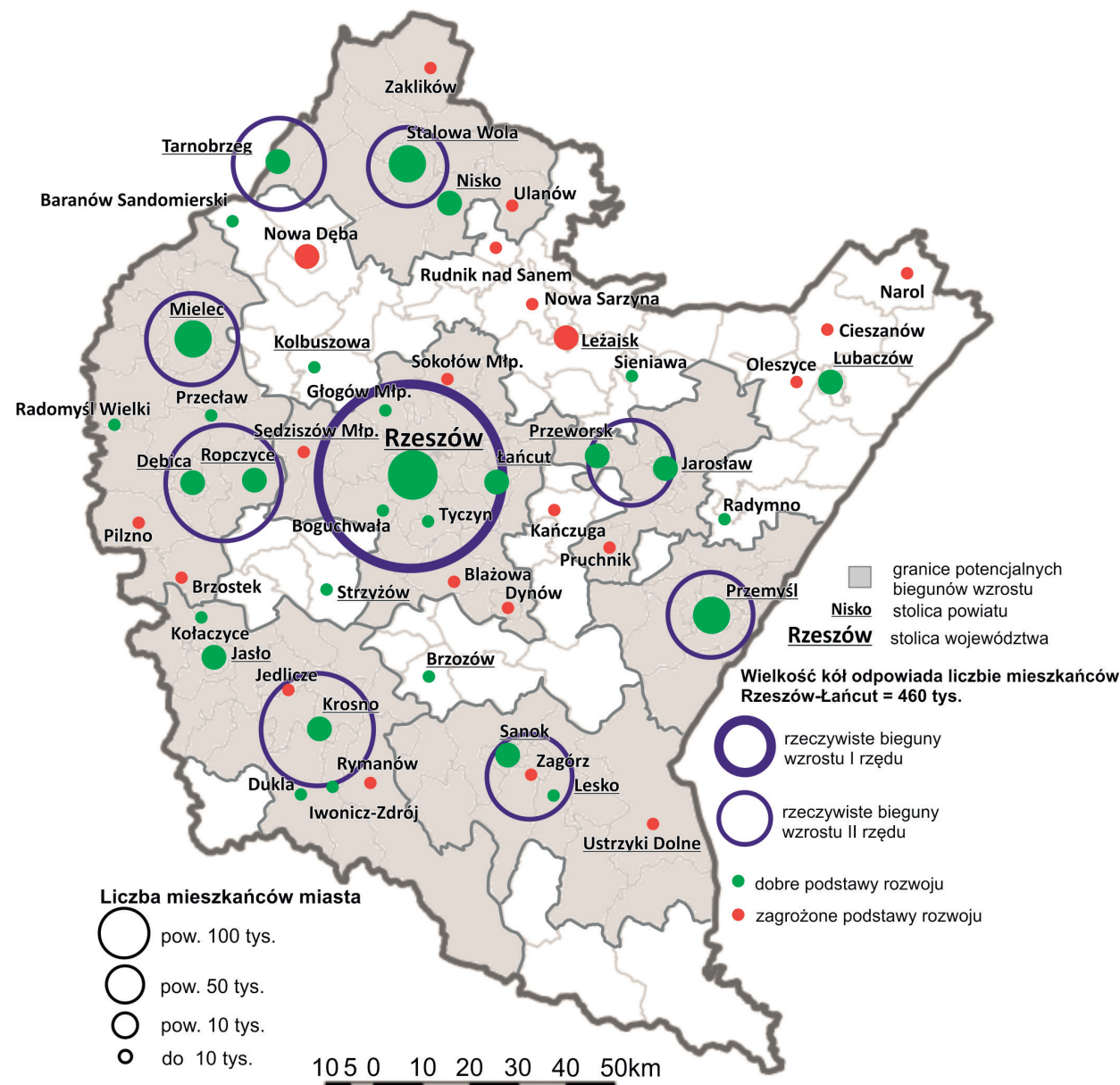

Ryc. 2. Bieguny wzrostu w województwie podkarpackim

Źródło: Bil, Łukomska 2016, s. 29 na podstawie: Komornicki i in. 2012.

${ }^{6}$ Zgodnie z KPZK 2030 miejski obszar funkcjonalny to układ osadniczy ciągły przestrzennie, złożony z odrębnych administracyjnie jednostek, obejmujący zwarty obszar miejski oraz powiązaną z nim funkcjonalnie strefę zurbanizowaną. Administracyjnie obszary te mogą obejmować gminy miejskie, wiejskie i miejsko-wiejskie. Miejskie obszary funkcjonalne można podzielić na cztery podtypy: ośrodków wojewódzkich (w tym metropolitalnych), regionalnych, subregionalnych i lokalnych. Delimitacja obszarów funkcjonalnych oraz przygotowanie strategii i planów zagospodarowania dla całego obszaru funkcjonalnego ośrodka miejskiego są obowiązkowe w przypadku wszystkich miast wojewódzkich (KPZK 2030, 2011, s. 187). 
Samorząd województwa prowadzi aktywną politykę miejską, dostrzegając potencjał zarówno Rzeszowa jako ośrodka posiadającego pewne funkcje metropolitalne, które należy rozwijać, jak i pozostałych ośrodków miejskich - ośrodków subregionalnych stanowiących bieguny wzrostu i szeregu mniejszych miast. Niezwykle istotna w ich rozwoju jest kwestia sieci powiązań.

Autorzy strategii rozwoju dużo miejsca poświęcili sieci osadniczej i samym miastom - jedna z czterech dziedzin działań strategicznych została określona jako „sieć osadnicza". Wśród mocnych stron w tej dziedzinie wymieniono m.in.:

- dobrze wykształconą i równomiernie rozmieszczoną strukturę hierarchiczną miast z niewielką przewagą największego ośrodka;

- Rzeszów jako silny ośrodek regionalny, pełniący szeroki zakres funkcji metropolitalnych;

- utrwalone i specyficzne funkcje wyróżniające poszczególne ośrodki subregionalne;

- bogatą sieć małych miast stanowiących lokalne ośrodki rozwoju i koncentracji usług dla otaczających je terenów.

Wskazano również słabe strony województwa w tym zakresie, m.in.:

- brak wystarczającej współpracy miast powiązanych układami funkcjonalnymi;

- zjawisko niekontrolowanej, chaotycznej suburbanizacji wokół ośrodków miejskich blokujące naturalny rozwój struktur miejskich, stwarzające utrudnienia komunikacyjne, powodujące nieład przestrzenny;

- brak sprawnego układu komunikacyjnego Rzeszowskiego Obszaru Funkcjonalnego (ROF) oraz ośrodków subregionalnych z ich obszarami funkcjonalnymi;

- wymagające rewitalizacji obszary miast;

- degradację ośrodków miejskich i osłabienie warunków ich rozwoju na skutek pogarszania sytuacji społeczno-ekonomicznej (Strategia rozwoju..., s. 14-15).

We wnioskach z diagnozy dotyczących sieci osadniczej województwa poza koniecznością poprawy infrastruktury drogowej czy szerokopasmowych sieci internetowych odniesiono się wyraźnie do kwestii polityki wobec ośrodków miejskich zauważając, że „cechą charakterystyczną województwa jest dość równomierny przestrzennie układ miejski tworzony przez Rzeszów i ośrodki subregionalne". Wobec tego faktu wskazano, że „policentryczny charakter systemu miejskiego województwa winien być zachowany przy równoczesnym wsparciu działań na rzecz zwiększenia potencjału demograficznego Rzeszowa" (Strategia rozwoju..., s. 21). W części tej zwrócono również uwagę na miasta mniejsze niż ośrodki subregionalne, używając pojęcia biegunów wzrostu: „rozwój województwa odbywa się poprzez istniejące i kształtujące się bieguny oraz strefy wzrostu, tworzone przez Rzeszów a także ośrodki subregionalne i powiatowe". Jako rekomendację w tym zakresie przyjęto: „konieczne jest wspieranie podstaw rozwojowych biegunów wzrostu oraz stymulowanie stref obejmujących bieguny także z województw: małopolskiego i świętokrzyskiego" (Strategia rozwoju..., s. 22). W części projekcyjnej strategii założono trzy scenariusze: szans (dynamicznie rozwija się Rzeszów wraz z jego obszarem funkcjonalnym oraz pozostałe bieguny wzrostu); pośredni (Rzeszów wraz z obszarem funkcjonalnym oraz bieguny wzrostu położone w północno-zachodniej 
części województwa rozwijają się, jednak te położone w południowej i wschodniej część regionu obejmuje proces zastoju gospodarczego); zagrożeń (następuje regres w rozwoju obszaru funkcjonalnego Rzeszowa oraz innych biegunów wzrostu, poza Mielcem).

W Strategii rozwoju województwa wskazano w sumie 19 priorytetów zgrupowanych w cztery dziedziny działań strategicznych. Zgodnie z zasadą terytorializacji interwencji wszystkie one zostały przypisane do pewnych obszarów geograficznych (najczęściej jednak całego obszaru województwa lub jego znaczącej części obejmującej wszystkie większe ośrodki miejskie). W efekcie wszystkie miasta uznane za bieguny wzrostu są celem większości postulowanych w strategii rozwoju interwencji (poza priorytetem 3.3 Funkcje metropolitalne Rzeszowa). Co więcej, nawet w przypadku uwzględnienia poziomu kierunków działań obraz jest podobny. Świadczyć to może o szczególnym znaczeniu biegunów wzrostu w polityce władz województwa, ale również o braku faktycznej terytorializacji większości działań.

W kontekście artykułu należy zwrócić szczególną uwagę na dwa priorytety: Funkcje metropolitalne Rzeszowa oraz Spójność przestrzenna i wzmacnianie funkcji biegunów wzrostu. Zostały tam zawarte szersze zalecenia, które mają wzmocnić poszczególne bieguny. Zalecenia w większości biegunów wzrostu są powiązane ze wszystkimi siłami konkurencyjności. Siły zasobów wewnętrznych oraz sieci dotyczą nawet wszystkich takich ośrodków (tabela 1).

Tabela 1

Działania w kierunku poprawy sytuacji społeczno-gospodarczej

w biegunach wzrostu postulowane w Strategii rozwoju województwa

\begin{tabular}{|c|c|c|c|c|c|c|}
\hline \multirow{2}{*}{$\begin{array}{c}\text { Biegun } \\
\text { wzrostu }\end{array}$} & \multirow{2}{*}{$\begin{array}{l}\text { Dzia- } \\
\text {-łania** }\end{array}$} & \multicolumn{4}{|c|}{ Siły konkurencyjności\%* } & \multirow{2}{*}{ Komentarz na podstawie ewaluacji Strategii rozwoju... } \\
\hline & & ZW & $\mathrm{PZ}$ & $\mathrm{D}$ & $\mathrm{S}$ & \\
\hline \multirow[b]{4}{*}{ Rzeszów } & A & + & + & + & + & \multirow{4}{*}{$\begin{array}{l}\text { Dobra realizacja wskaźników związanych z demografią } \\
\text { oraz bardzo dobra - wskaźników związanych z rozwo- } \\
\text { jem gospodarczym. Mimo tego z powodu braku danych } \\
\text { w systemie monitoringu nie można jednoznacznie } \\
\text { określić stopnia realizacji dwóch pierwszych działań. } \\
\text { Zróżnicowane wartości wskaźników opisujących dzia- } \\
\text { łania C (największym problemem jest brak przyrostu } \\
\text { długości dróg o nawierzchni twardej ulepszonej) oraz D. } \\
\text { W kontekście priorytetu bardzo ważnym wydarzeniem } \\
\text { było wdrożenie instrumentu Zintegrowanych Inwestycji } \\
\text { Terytorialnych i uchwalenie Strategii ZIT Rzeszowskie- } \\
\text { go Obszaru Funkcjonalnego, która może mieć znaczący } \\
\text { wpływ na realizację działań C i D. }\end{array}$} \\
\hline & B & + & + & + & & \\
\hline & $\mathrm{C}$ & & & & + & \\
\hline & $\mathrm{D}$ & + & & & + & \\
\hline \multirow[b]{2}{*}{ Przemyśl } & A & + & & + & & \multirow{2}{*}{$\begin{array}{l}\text { Biegun borykający się ze znacznymi problemami rozwo- } \\
\text { jowymi. Wartość docelowa zdecydowanej większości } \\
\text { wskaźników nie została dotychczas osiągnięta, zaś } \\
\text { trend zmian ich wartości podaje w wątpliwość szanse } \\
\text { na ich wypełnienie w perspektywie kilku lat. Dzieje się } \\
\text { tak pomimo stosunkowo niskich wymaganych wartości } \\
\text { docelowych w porównaniu z innymi ośrodkami. }\end{array}$} \\
\hline & B & + & & & + & \\
\hline
\end{tabular}


Tabela $1 \mathrm{~cd}$

\begin{tabular}{|c|c|c|c|c|c|c|}
\hline \multirow{2}{*}{$\begin{array}{l}\text { Biegun } \\
\text { wzrostu }\end{array}$} & \multirow{2}{*}{$\begin{array}{l}\text { Dzia- } \\
\text {-łania* }\end{array}$} & \multicolumn{4}{|c|}{ Siły konkurencyjności** } & \multirow{2}{*}{ Komentarz na podstawie ewaluacji Strategii rozwoju... } \\
\hline & & ZW & $\mathrm{PZ}$ & $\mathrm{D}$ & $\mathrm{S}$ & \\
\hline \multirow[b]{2}{*}{$\begin{array}{l}\text { Stalowa } \\
\text { Wola }\end{array}$} & A & + & & & & \multirow{2}{*}{$\begin{array}{l}\text { Sytuacja bieguna wzrostu jest stosunkowo dobra. Osiąg- } \\
\text { nięte zostały już wartości części wskaźników monito- } \\
\text { ringu Strategii rozwoju... Ważna w dalszym rozwoju } \\
\text { jest kwestia dyfuzji czynników rozwojowych w kierunku } \\
\text { Tarnobrzega, co w efekcie może zaowocować powsta- } \\
\text { niem duopolu (lub nawet większego układu obejmują- } \\
\text { cego też Sandomierz). }\end{array}$} \\
\hline & B & + & + & + & + & \\
\hline \multirow[b]{2}{*}{ Mielec } & A & + & & & & \multirow{2}{*}{$\begin{array}{l}\text { Ośrodek subregionalny w najlepszej sytuacji społeczno- } \\
\text {-gospodarczej. Dotyczy to zwłaszcza sfery gospodarczej. } \\
\text { Wartości docelowe większości wskaźników ze Strategii } \\
\text { rozwoju... już zostały osiągnięte. Mimo wszystko należy } \\
\text { zwracać uwagę na pewne kwestie - zwłaszcza związane } \\
\text { z utrudnioną dostępnością transportową, zwłaszcza } \\
\text { kolejową. }\end{array}$} \\
\hline & B & + & + & + & + & \\
\hline \multirow[b]{2}{*}{$\begin{array}{l}\text { Tarno- } \\
\text { brzeg }\end{array}$} & A & + & & & & \multirow{2}{*}{$\begin{array}{l}\text { Biegun borykający się ze znacznymi problemami rozwo- } \\
\text { jowymi. Wartość docelowa zdecydowanej większości } \\
\text { wskaźników nie została dotychczas osiągnięta, zaś trend } \\
\text { zmian ich wartości podaje w wątpliwość szanse na ich } \\
\text { wypełnienie w perspektywie kilku lat. Ważną kwestią } \\
\text { jest dyfuzja czynników rozwojowych na otaczające } \\
\text { obszary. }\end{array}$} \\
\hline & B & + & + & & + & \\
\hline \multirow[b]{2}{*}{ Krosno } & A & + & + & & & \multirow{2}{*}{$\begin{array}{l}\text { Sytuacja bieguna wzrostu jest stosunkowo dobra. } \\
\text { Osiągnięte zostały już wartości części wskaźników mo- } \\
\text { nitoringu Strategii rozwoju... W dalszym ciągu należy } \\
\text { jednak podejmować działania mające na celu rozwijanie } \\
\text { i lepsze wykorzystanie oferty turystycznej obszaru. }\end{array}$} \\
\hline & B & + & + & + & + & \\
\hline $\begin{array}{l}\text { Dębica- } \\
\text {-Ropczyce }\end{array}$ & A & + & + & & + & \multirow{3}{*}{$\begin{array}{l}\text { Bieguny nieobjęte dokładnym badaniem w ramach } \\
\text { ewaluacji. Pozostałe badania wskazują na konieczność } \\
\text { intensyfikacji działań w biegunach, ze szczególnym } \\
\text { ukierunkowaniem na tworzenie układów multipolar- } \\
\text { nych. }\end{array}$} \\
\hline $\begin{array}{l}\text { Jarosław- } \\
\text {-Przeworsk }\end{array}$ & A & + & & & + & \\
\hline $\begin{array}{l}\text { Sanok- } \\
\text {-Lesko }\end{array}$ & A & + & + & + & + & \\
\hline
\end{tabular}

* Opisy działań znajdują się w załączniku nr 1.

** ZW - zasoby wewnętrzne, PZ - popyt zewnętrzny, D - dominacja, S - sieci.

Źródło: opracowanie własne na podstawie: Strategia rozwoju...

Ponadto we wszystkich biegunach wzrostu mają być koncentrowane działania związane z rozwojem powiązań komunikacyjnych wewnątrz obszarów funkcjonalnych oraz z rewitalizacją i poprawą ładu przestrzennego (siła zasobów wewnętrznych oraz siła sieci). Działania koncentrowane w biegunach wzrostu mają sprawić, że łączyć się one będą w większe układy mulitipolarne, obejmujące większą liczbę ośrodków miejskich, czasem również spoza obszaru województwa (np. Sandomierz). Wskazano również 
potencjalny biegun wzrostu, jakim miałby być Lubaczów mający obsługiwać potrzeby północno-wschodniej części województwa.

\section{Podsumowanie i wnioski}

Kwestia rozwoju miast (wraz z ich obszarami funkcjonalnymi) jest przez władze województwa podkarpackiego traktowana poważnie, o czym świadczą opracowania dotyczące tej kwestii oraz jej miejsce w dokumentach strategicznych. Założenia polityki intraregionalnej pokazują, że władze niewątpliwie w sposób aktywny chcą stymulować rozwój regionalnych biegunów wzrostu. W odniesieniu do koncepcji czterech sił konkurencyjności podkarpackie bieguny wzrostu swą przewagę budują często w obrębie wszystkich definiowanych tak sił. W prowadzonych badaniach zwraca uwagę przywiązywanie dużej wagi do zagadnień takich jak np.: demografia (siła zasobów wewnętrznych), inteligentne specjalizacje (siła popytu zewnętrznego, siła dominacji) czy rozprzestrzenianie trendów rozwojowych poza obszar biegunów wzrostu i ich łączenie się (siła sieci). Zdecydowanie najsilniejszym biegunem wzrostu w regionie jest ROF, obszar szczególnie konkurencyjny w odniesieniu do wszystkich czterech omawianych sił. Stąd szczególne znaczenie dla rozwoju regionu Rzeszowa, ośrodka potrzebującego jednak dokończenia kluczowych inwestycji wzmacniających jego stołeczność wojewódzką oraz rozwoju inwestycji służących lepszej dostępności komunikacyjnej miasta z innymi ośrodkami w regionie (drogi, kolej). Sytuacja w pozostałych biegunach wzrostu jest gorsza, a rokowania co do ich rozwoju mniej pewne. Miasta te wymagają różnorakich działań rozwojowych mających na celu ograniczenie odpływu mieszkańców, stymulację wzrostu gospodarczego i wchodzenie w sieci powiązań. W podejściu do danego ośrodka konieczne jest jednak wspieranie potencjałów dostosowanych do jego specyfiki. Wymagają one więc dobrze ukierunkowanych interwencji, niekoniecznie budowania przewagi konkurencyjnej w obrębie wszystkich czterech sił konkurencyjności. W regionie występuje również dużo niewielkich ośrodków miejskich, a stopień urbanizacji jest najniższy w kraju. Stąd też wskazywaną szansą dla rozwoju tak ukształtowanego regionu jest „policentryczna koncentracja”. Chociaż siły rynkowe powodują koncentrację zasobów w biegunach wzrostu (zwłaszcza w Rzeszowie), to jednak ośrodki subregionalne i lokalne muszą mieć zidentyfikowane minima interwencji wspieranych przez samorząd wojewódzki. Warto zwrócić uwagę również na kwestie migracji wewnątrz regionu - gdzie kluczowe zdaje się wzmocnienie ośrodków powiatowych, które powinny pełnić wysokiej jakości centra usług publicznych i lokalnych rynków pracy, aby zapobiec procesom ich szybkiego wyludniania się (Dziemianowicz 2016b, s. 183-185). 
Załącznik 1

\section{Działania wobec biegunów wzrostu}

\section{postulowane w Strategii rozwoju województwa - Podkarpackie 2020}

\section{(s. 62-65, 67-70)}

\section{Rzeszów:}

(A) Tworzenie korzystnych warunków do trwałego wzrostu gospodarczego; (B) Wzmacnianie funkcji metropolitalnych realizowanych przez Rzeszów oraz wspieranie rozwoju nowych funkcji zwiększających zakres świadczonych usług wyższego rzędu; (C) Rozwój powiązań komunikacyjnych i zintegrowanego systemu transportu publicznego łączących Rzeszów z jego obszarem funkcjonalnym; (D) Uporządkowanie gospodarki przestrzennej Rzeszowa i integracja w ramach obszaru funkcjonalnego.

Przemyśl:

(A) Wzmocnienie roli bieguna wzrostu w świadczeniu usług publicznych oraz usług wyższego rzędu oraz wysoka jakość kapitału ludzkiego; (B) Rozwój potencjału gospodarczego bieguna wzrostu wraz z rozprzestrzenianiem trendów rozwojowych na otaczające go obszary funkcjonalne, w szczególności w oparciu o predyspozycje do rozwoju funkcji logistycznych na kierunku wschód-zachód, funkcji handlowych transgranicznych (Ukraina).

Stalowa Wola:

(A) Wzmocnienie roli bieguna wzrostu w świadczeniu usług publicznych oraz usług wyższego rzędu; (B) Rozwój potencjału gospodarczego bieguna wzrostu wraz z rozprzestrzenianiem trendów rozwojowych na otaczające go obszary funkcjonalne.

Mielec:

(A) Wzmocnienie roli bieguna wzrostu w świadczeniu usług publicznych oraz usług wyższego rzędu; (B) Rozwój potencjału gospodarczego bieguna wzrostu wraz z rozprzestrzenianiem trendów rozwojowych na otaczające go obszary funkcjonalne, w szczególności w oparciu o potencjał dla rozwoju przemysłu lotniczego, zaplecze w postaci lokalizacji dużych międzynarodowych przedsiębiorstw prowadzących badania i wdrażających innowacje.

\section{Tarnobrzeg:}

(A) Wzmocnienie roli bieguna wzrostu w rozwoju funkcji rekreacyjnych i wykorzystania dużego kapitału ludzkiego do rozwoju usług opartych na wiedzy; (B) Rozwój potencjału gospodarczego bieguna wzrostu posiadającego korzystne położenie na osi silnych relacji ekonomicznych Rzeszów-Warszawa wraz z rozprzestrzenianiem trendów rozwojowych na otaczające go obszary funkcjonalne (wraz z podjęciem działań zmierzających do utworzenia układu multipolarnego razem ze Stalową Wolą i Sandomierzem).

Krosno:

(A) Wzmocnienie roli bieguna wzrostu w świadczeniu usług publicznych oraz usług wyższego rzędu, w szczególności opartych na potencjale do rozwoju usług turystycznych (centrum dziedzictwa szkła) i kulturalnych; (B) Rozwój potencjału gospodarczego bieguna wzrostu wraz z rozprzestrzenianiem trendów rozwojowych na otaczające go obszary funkcjonalne, w szczególności w oparciu o możliwości wzmocnienia powiązań gospodarczych ze Słowacją oraz wykorzystania potencjału sąsiednich uzdrowisk: Iwonicz-Zdrój, Rymanów i wykorzystanie bogatych tradycji, wieloletnich doświadczeń oraz szerokiej bazy infrastrukturalnej w dziedzinie przemysłu szklarskiego, lotniczego i maszynowego.

Dębica-Ropczyce:

(A) Rozwój potencjału gospodarczego bieguna wzrostu wraz z rozprzestrzenianiem trendów rozwojowych na otaczające go obszary funkcjonalne, w szczególności w oparciu o dobrą dostępność komunikacyjną w układzie wschód-zachód umożliwiającą rozwój usług transportowych, w którym znajdują się przedsiębiorstwa działające w skali międzynarodowej (w szczególności przemysł gumowy i chemiczny); 
Jarosław-Przeworsk:

(A) Rozwój potencjału gospodarczego bieguna wzrostu wraz z rozprzestrzenianiem trendów rozwojowych na otaczające go obszary funkcjonalne, w szczególności do pełnienia funkcji kulturalnych oraz rozwijania powiązań gospodarczych z Ukrainą.

Sanok-Lesko:

(A) Rozwój potencjału gospodarczego bieguna wzrostu wraz z rozprzestrzenianiem trendów rozwojowych na otaczające go obszary funkcjonalne, w szczególności w oparciu o potencjał w zakresie obsługi ruchu turystycznego Bieszczad.

\section{Bibliografia}

Bil M., Łukomska J., 2016, Miejska sieć osadnicza województwa podkarpackiego, [w:] Dziemianowicz W., Charkiewicz J. (red.), Miasta województwa podkarpackiego-perspektywy rozwoju. Raport końcowy, Urząd Marszałkowski Województwa Podkarpackiego, Rzeszów.

Charkiewicz J., Ostrowska A., Pawluczuk M., 2011, Subregionalne bieguny wzrostu w strategiach regionalnych, [w:] Dziemianowicz W., Szlachta J., Szmigiel-Rawska K. (red.), Subregionalne bieguny wzrostu, Wydział Geografii i Studiów Regionalnych, Warszawa.

Dunford M., 2003, Theorizing regional economic performance and the changing territorial division of labor, „Regional Studies” vol. 37/8.

Dziemianowicz W., 2008, Konkurencyjność gmin w kontekście relacji władze lokalne - inwestorzy zagraniczni, Wydawnictwo Uniwersytetu Warszawskiego, Warszawa.

Dziemianowicz W., 2011, Subregionalne bieguny wzrostu - od teorii do hipotez badawczych, [w:] Dziemianowicz W., Szlachta J., Szmigiel-Rawska K. (red.), Subregionalne bieguny wzrostu, Wydział Geografii i Studiów Regionalnych, Warszawa.

Dziemianowicz W., 2016a, Miasta Podkarpacia „2016” - synteza, [w:] Dziemianowicz W., Charkiewicz J. (red.), Miasta województwa podkarpackiego - perspektywy rozwoju. Raport końcowy, Urząd Marszałkowski Województwa Podkarpackiego, Rzeszów.

Dziemianowicz W., 2016b, Polityka rozwoju miast i obszarów funkcjonalnych na Podkarpaciu, [w:] Dziemianowicz W., Charkiewicz J. (red.), Miasta województwa podkarpackiego - perspektywy rozwoju. Raport końcowy, Urząd Marszałkowski Województwa Podkarpackiego, Rzeszów.

Dziemianowicz W., Charkiewicz J., Laskowska A. (red.), 2016, Raport z realizacji Strategii rozwoju województwa - Podkarpackie 2020 za okres 2013-2016 z odniesieniem do nowych elementów modelu programowania polityki rozwoju. Raport końcowy, Geoprofit, Warszawa-Rzeszów.

Gawlikowska-Hueckel K., 2003, Procesy rozwoju regionalnego w Unii Europejskiej. Konwergencja czy polaryzacja?, Wydawnictwo Uniwersytetu Gdańskiego, Gdańsk.

Gorzelak G., Płoszaj A., Smętkowski M., 2006, Ocena strategii rozwoju regionu - wykorzystanie modelu czterech kapitałów, „Studia Regionalne i Lokalne” nr 3(25).

Grosse T.G., 2002, Przeglad koncepcji teoretycznych rozwoju regionalnego, „Studia Regionalne i Lokalne” 1(8).

Grzeszczak J., 1971, Koncepcje polaryzacyjne w przestrzennym zagospodarowaniu kraju. Na przykładzie Francji, KPZK PAN, Warszawa. Studia t. 36.

Grzeszczak J., 1978, Teoria biegunów wzrostu, Zakład Narodowy im. Ossolińskich, Wrocław-WarszawaKraków-Gdańsk. Przegląd Zagranicznej Literatury Geograficznej z. 3-4.

Grzeszczak J., 1999, Bieguny wzrostu a formy przestrzeni spolaryzowanej, Continuo, Wrocław. Prace Geograficzne - IGiPZ PAN nr 173.

Higgins B., Savoie D.J., 1997, Regional development theories and their application, Transaction Publishers, New Jersey.

Jałowiecki B., 1999, Metropolie, Wyższa Szkoła Finansów i Zarządzania w Białymstoku, Białystok.

Komornicki T., Śleszyński P., Siłka P., 2012, Charakterystyka systemu osadniczego województwa podkarpackiego z identyfikacją biegunów wzrostu oraz wyróżnieniem obszarów funkcjonalnych na poziomie regionalnym i lokalnym, IGIPZ PAN, Warszawa. 
Koncepcja Przestrzennego Zagospodarowania Kraju 2030, 2011, Ministerstwo Rozwoju Regionalnego, Warszawa.

Krajowa Polityka Miejska 2023, 2015, Ministerstwo Rozwoju, Warszawa.

Krajowa Strategia Rozwoju Regionalnego 2010-2020: regiony, miasta, obszary wiejskie, 2010, Ministerstwo Rozwoju Regionalnego, Warszawa.

Leydesdorff L., 2012, The triple helix, quadruple helix, ..., and an n-tuple of helices: Explanatory models for analyzing the knowledge-based economy?, „Journal of the Knowledge Economy” vol. 3, Is. 1.

Łukomska J., 2016, Wskaźnik syntetyczny rozwoju - metodyka, [w:] Dziemianowicz W., Charkiewicz J. (red.), Miasta województwa podkarpackiego - perspektywy rozwoju. Raport końcowy, Urząd Marszałkowski Województwa Podkarpackiego, Rzeszów.

Malizia E.E., Feser E.J., 1999, Understanding local economic development, Center for Urban Policy Research, Rutgers, The State University of New Jersey, New Jersey.

Nelson A.C., 1993, Theories of regional development, [w:] Bingham R.D., Mier R. (eds.), Theories of local economic development. Perspectives from across the disciplines, Sage Publications, Newbury Park- London- New Delhi.

Nowicka P., 2011, Subregionalne bieguny w badaniach ankietowych, [w:] Dziemianowicz W., Szlachta J., Szmigiel-Rawska K. (red.), Subregionalne bieguny wzrostu, Wydział Geografii i Studiów Regionalnych, Warszawa.

Perroux F., 1955, Note sur la notion de „pôle de croissance”, „Economie Appliquée” t. 8(1-2).

Płoszaj A., 2007, Cztery kapitały w strategiach lokalnych, [w:] Gorzelak G (red.), Polska regionalna i lokalna w świetle badań EUROREG-u, Wydawnictwo Naukowe Scholar, Warszawa.

Smętkowski M., 2013, Miasta jako bieguny rozwoju, [w:] Olechnicka A., Wojnar K. (red.), Terytorialny wymiar rozwoju - Polska z perspektywy badań ESPON, Wydawnictwo Naukowe Scholar, Warszawa.

Strategia rozwoju województwa - Podkarpackie 2020, 2013, Samorząd Województwa Podkarpackiego, Rzeszów.

Szlachta J., 2011, Ośrodki subregionalne w Polsce - identyfikacja, Dziemianowicz W., Szlachta J., Szmigiel-Rawska K. (red.), Subregionalne bieguny wzrostu, Wydział Geografii i Studiów Regionalnych, Warszawa.

Wojnicka-Sycz E., 2013, Model terytorialnego bieguna wzrostu jako system czynników rozwojowych, Wydawnictwo Uniwersytetu Gdańskiego, Gdańsk. 